\title{
原發性 肺臟癌
}

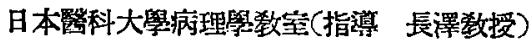

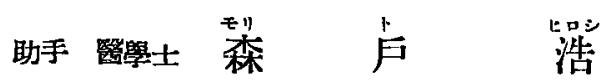

第 1 章 緒 言

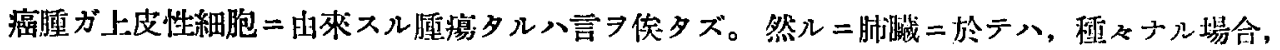
組織學的二著明＝檢出セラルル所調脯胞上皮細胞二關シテ八，今日攸りノ本態ニツキ諸家ノ意

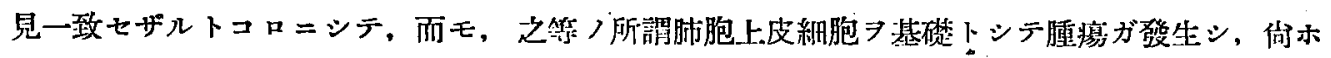

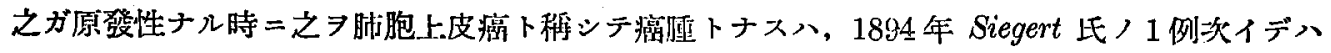
1902 年 Dömeny 氏ノ發表ヨ始メトシテ, 一部諸家ノ認ムルトコロナリ。

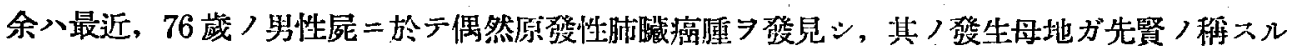
所謂肺胞上皮細胞二ハ非ズャノ所兒ヨ有スル症例ニシテ, 而モ, コノ發生母地二對シ食ノ管兒

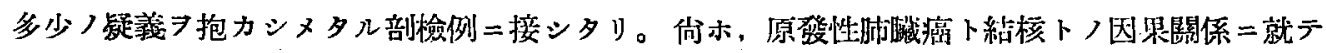

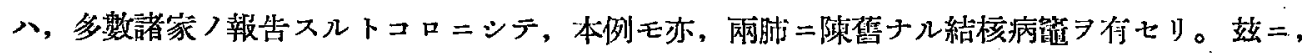

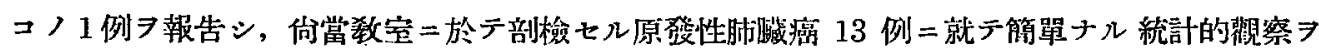
爲シ, 先輩諸賢〉御批制

\section{第 2 章 苗 驗 例}

\section{第 1 項 臨彇記鑯}

患者。乐O大O。76 歲, 男。

家族歴っ惡性唖鹰，遇傳的關保其，他特記 スベキュトナシ。

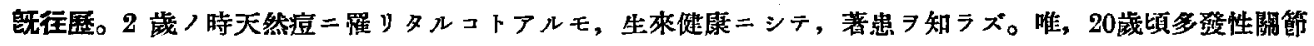
「ロイマチスムス」籍リタルコトアリト言つ。

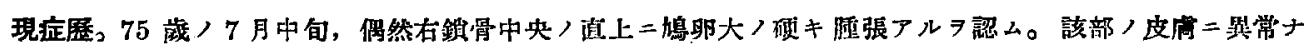

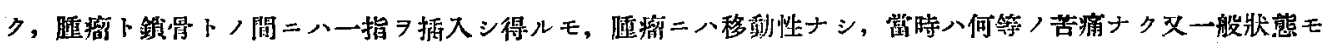

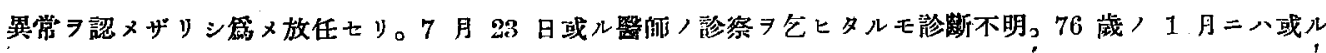

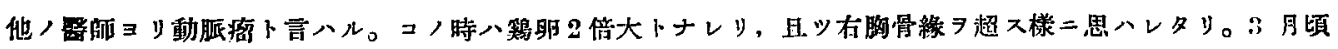

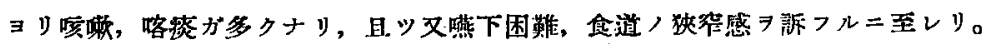

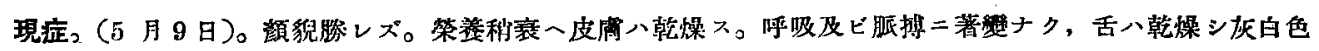

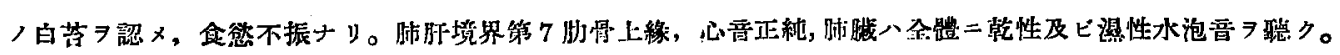

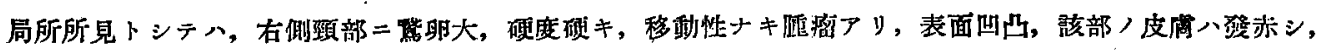

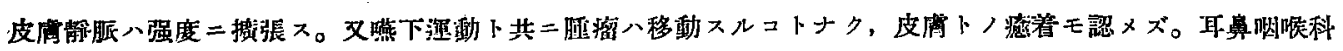

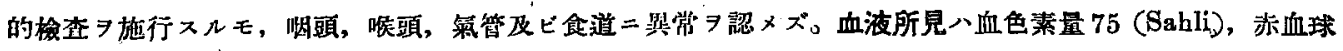
$3.74 \times 10^{6}$, 白血球 $77 \times 10^{2}$, 白血球，租類ハ「エオジン」啫好性細胞 $3.0 \%$, 大單核細胞及移行型 $5.0 \%$, 淋巴 
球 $13.0 \%$ ，中性啫好性勫胞 $77.0 \%$ ニシテ多少/而血及ビ淋巴球/減少少認メラル。赤血球沈降速度八 1 時 間目 62,2 時間目 96 ニシテ非常ニ促道セり。尿八蛋白,「ウロビリン」及ビ「ウロビリノニゲン」习陽性二 認メタルモ，他ノ薢化二就テハ明記ナシ。

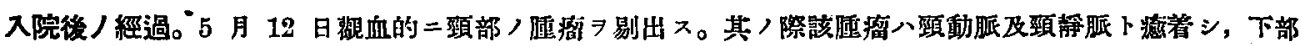

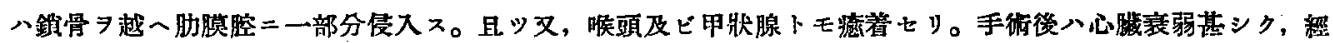
過不良ニシテ5月 15 日逐二鬼籍ニ入ル。

\section{第 2 項 病理解剖學的所見。}

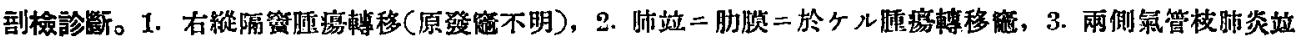

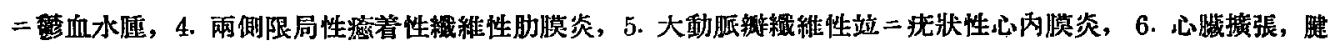

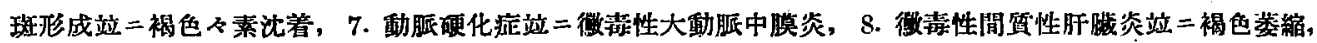

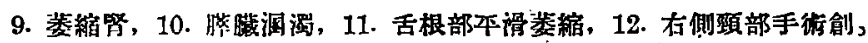

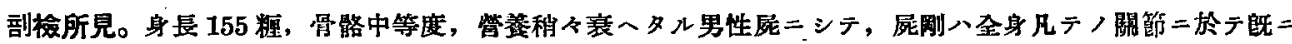

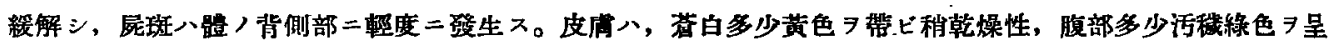

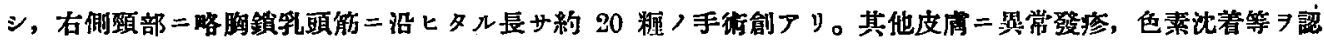

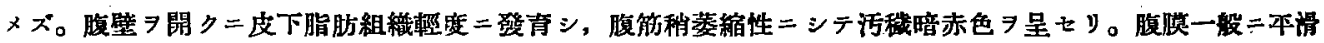

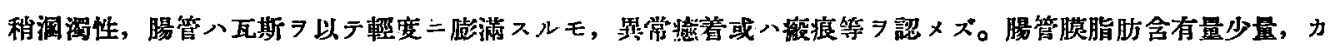

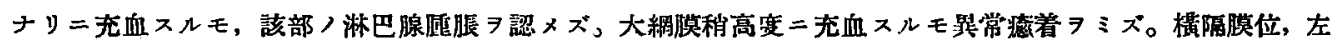

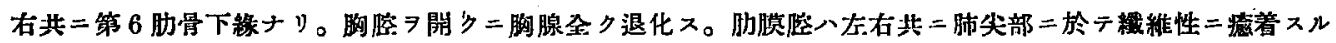

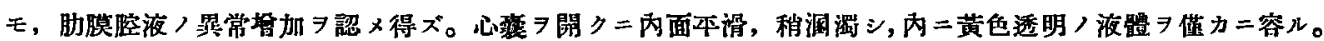

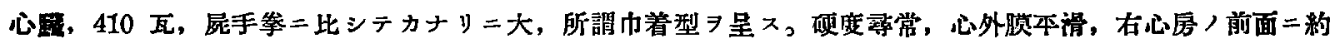

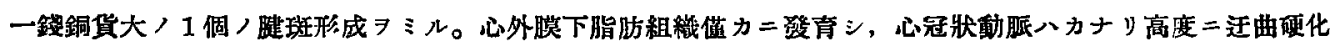

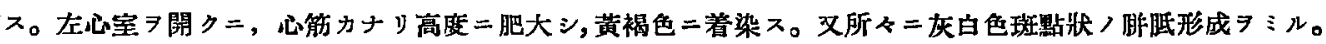

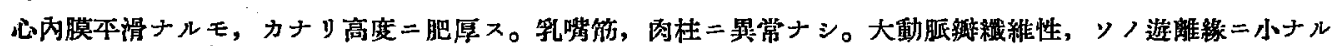

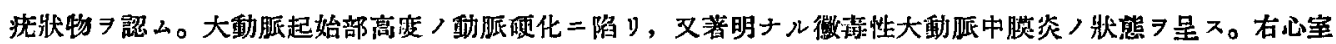

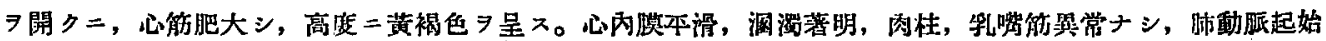

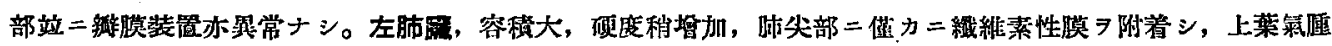
狀,下葉前面二灰白色, 䋐維性

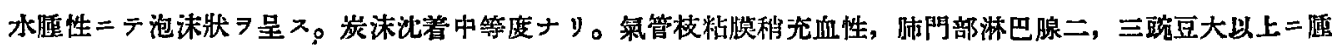

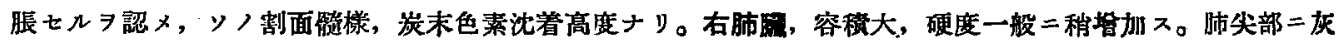
白色, 不規則 / 㢣縮部 7 認 $x$, 悢維性膜 ル肋膜面八稍肥厚シ, 諸所二灰白色, 米粒大八限局性結節 7 多數散在性二認么。其八結節八肋膛二限局サレ

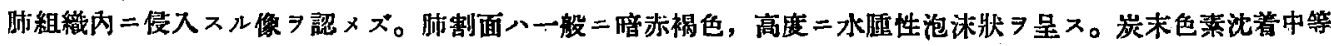

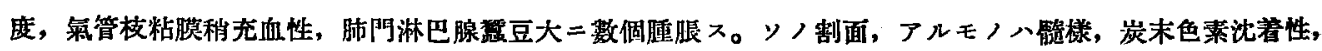
或ルモノ八灰白色ニシテ婳熘轉移ヨ思ハシム。

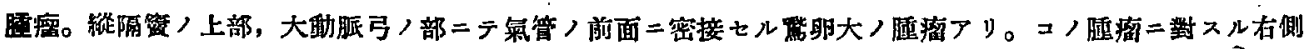




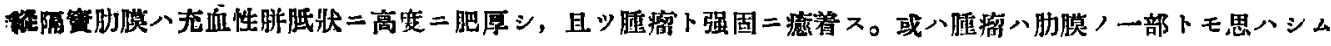

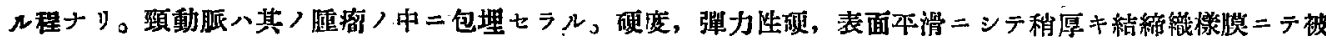

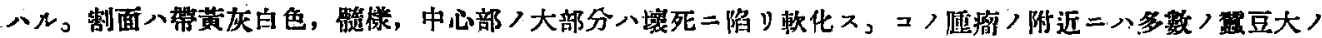

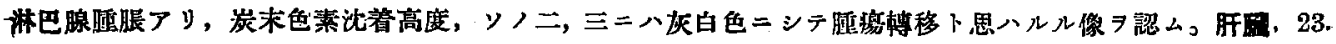
$0 \times 14.0 \times 5.9$ 糎, 950 瓦, 硬度尋常, 表面僅カ二小顆粒狀, 割面一般二黄褐色, 稍洞濁性, 肝小葉像著明二

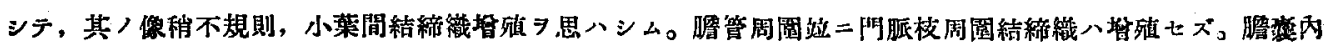

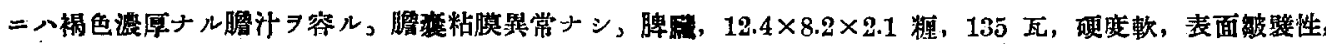

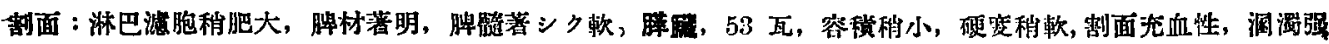

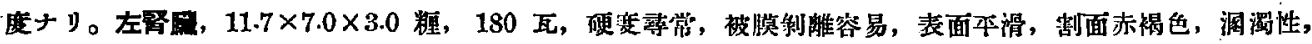

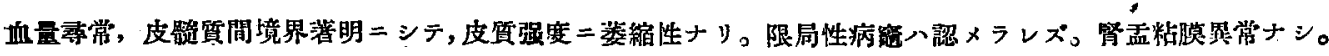

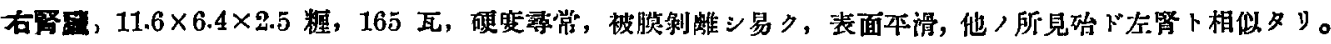

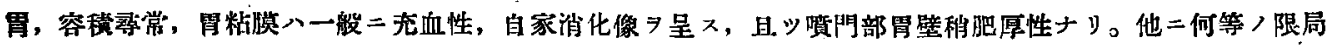

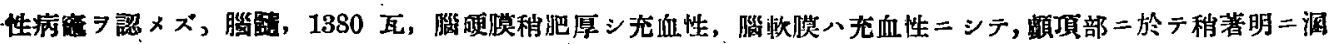

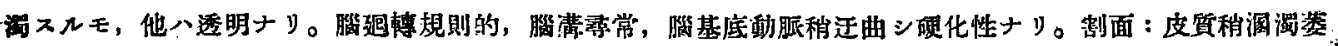

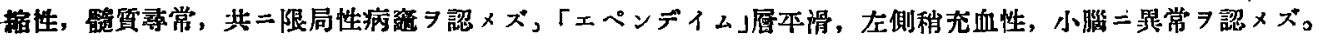

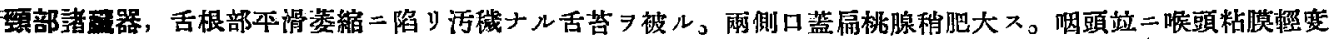

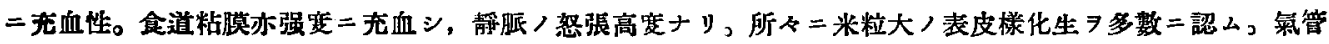

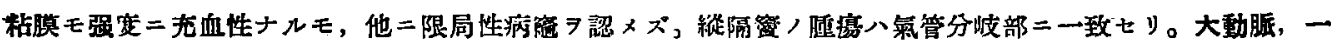

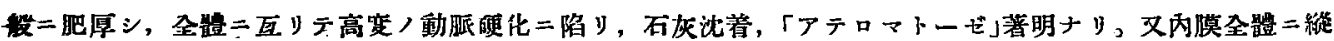
走七几铍倠习著明二認么,

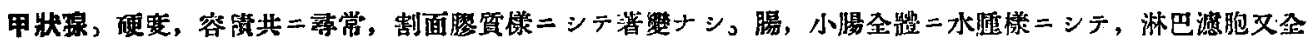

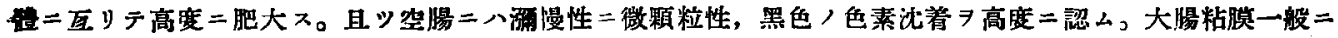
水腫性，充血性ニシテ著變习認メズ。

\section{第 3 項 病理組織學的所見}

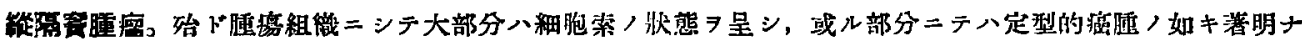

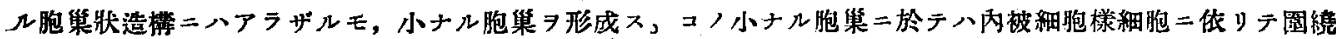

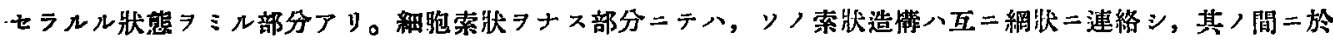
ケル結䋨織八多少砂子栐 7 呈ス。又檢索場所ニヨリテハ標本全體二出血强度ニシテ, 或ル部分二テハ炭末色

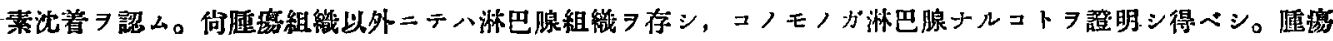

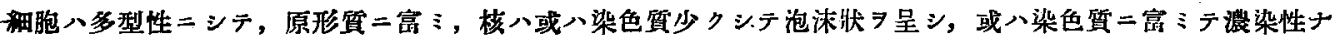

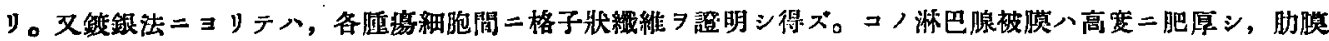

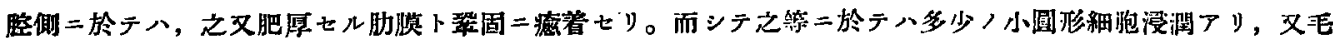

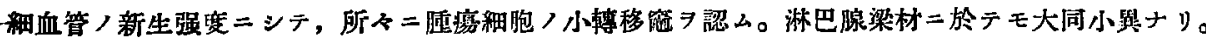

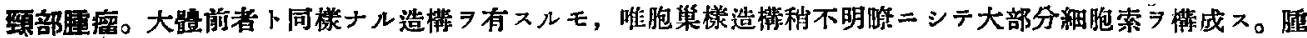

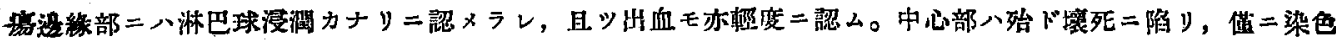




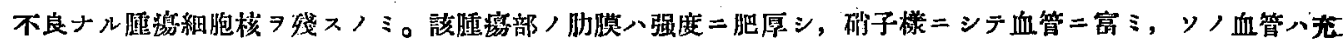

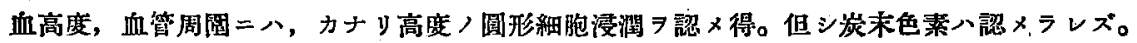

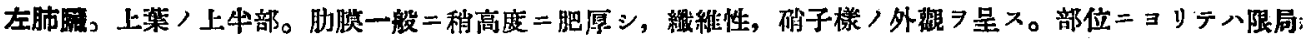

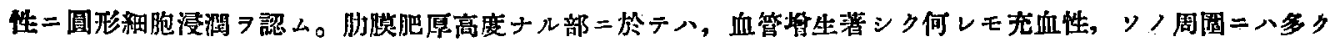

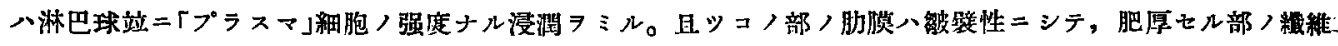

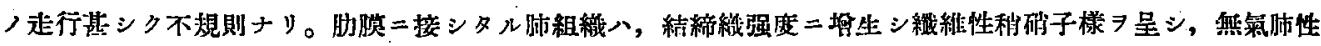

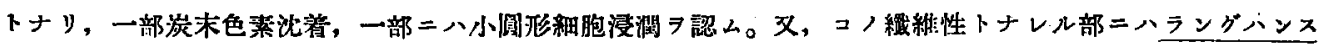

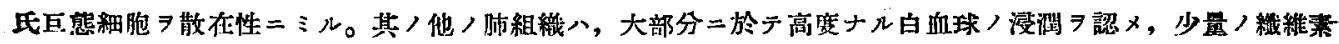

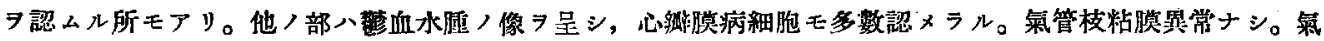

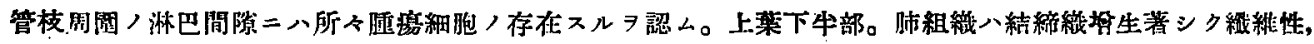

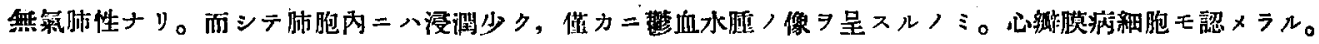

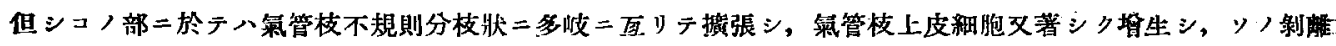

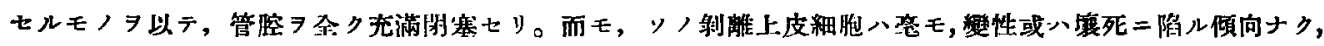

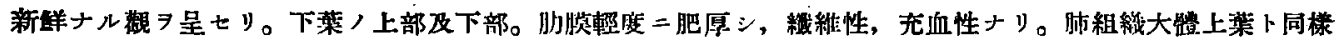

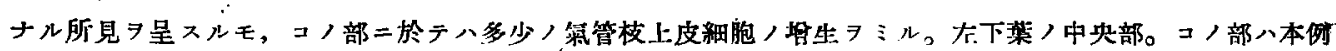

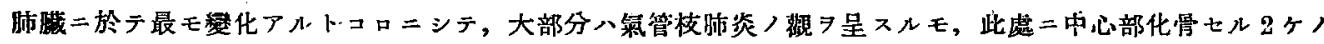

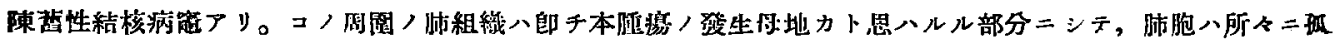

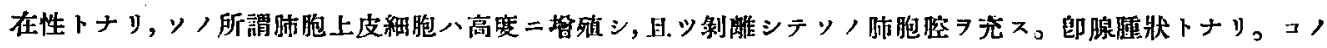

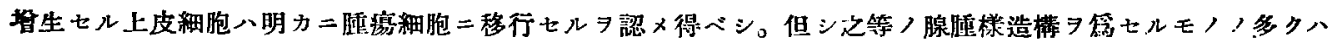

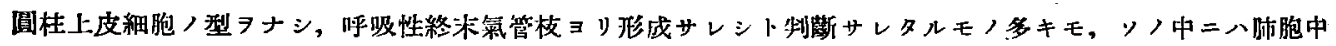

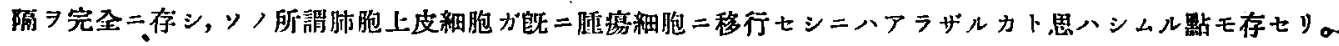

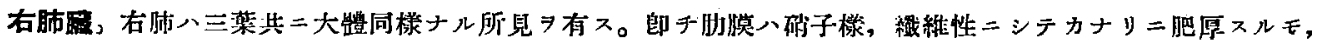

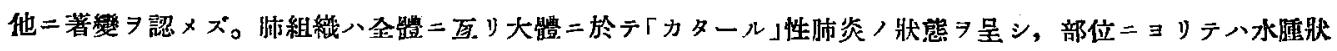

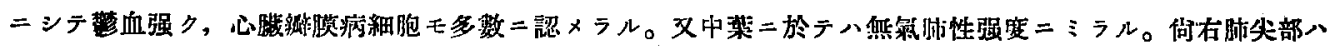

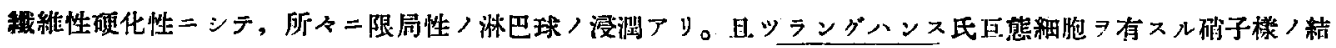

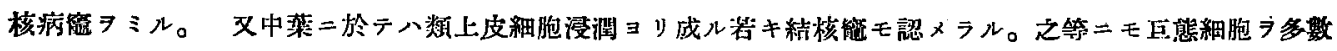

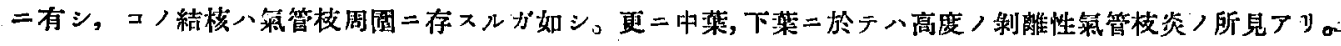

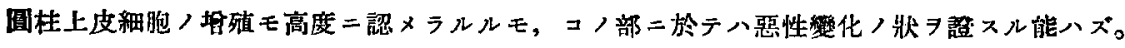

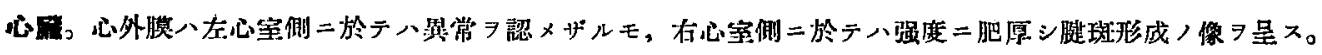

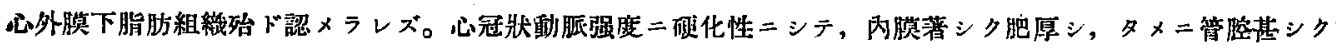

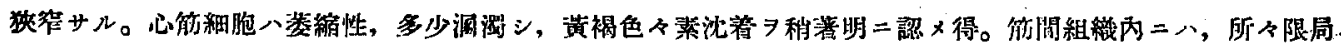
珄二多少，圆形細胞浸膶アリ。心內膜筫管ナシ。

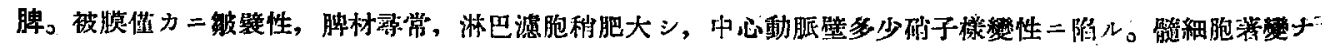
ク, 靜脈僅カ二篗血性ナり。

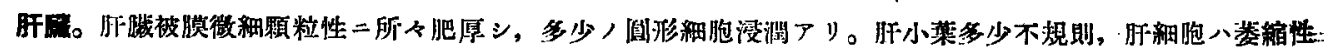




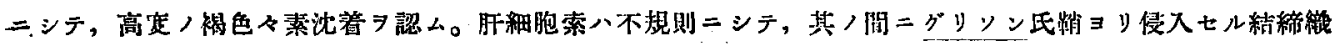

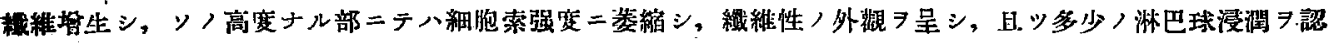

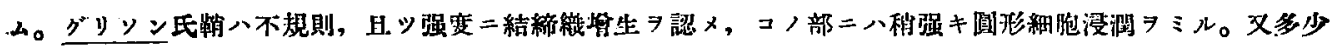

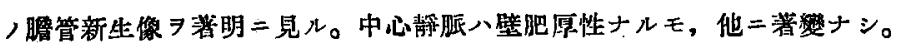

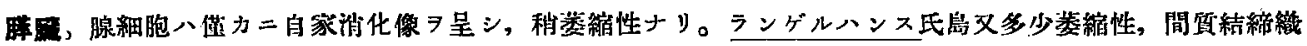
稍等加シ，血管硬化性ナり。

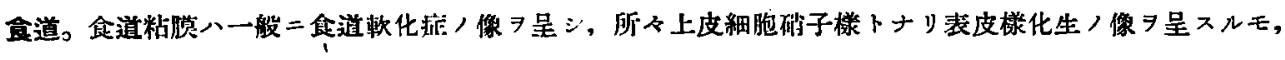

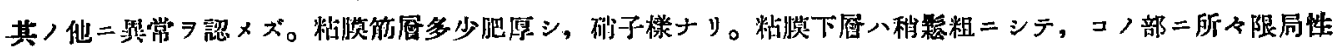

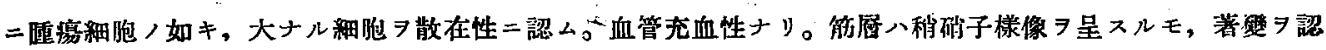
$x \not ゙ 。$

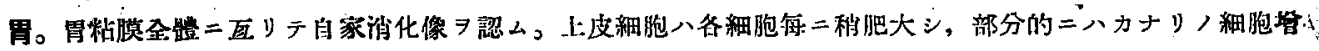

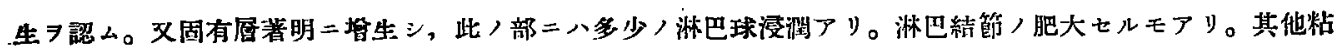
笑称稍肥厚七几以外二八著變习認メズ。

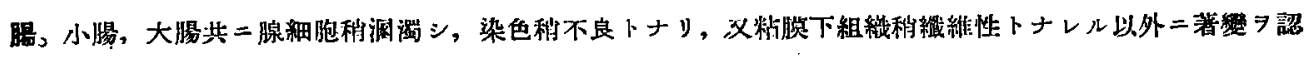
メズ。

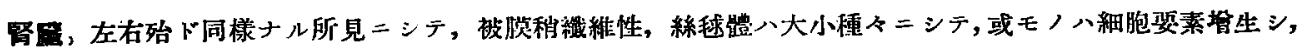

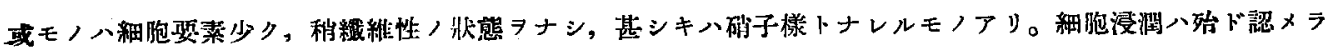

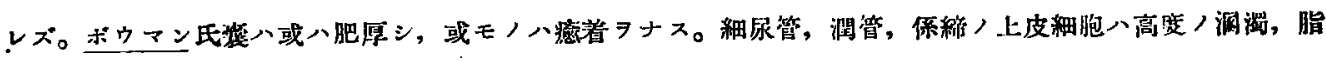

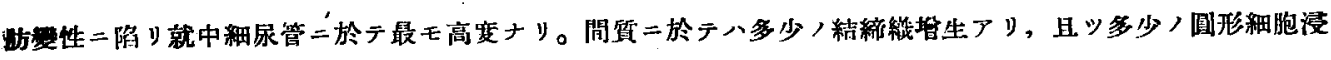

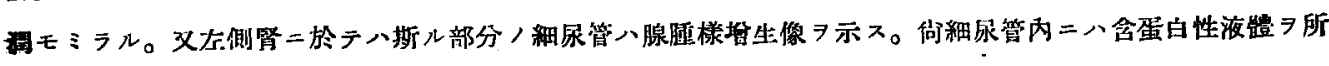
タ見ル。腎血管ハカナリ二肥厚シ，释維性トナル。

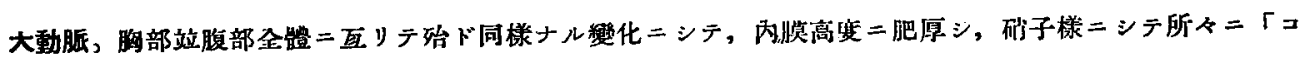

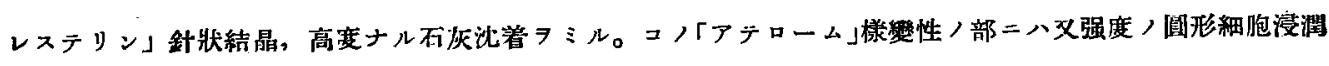

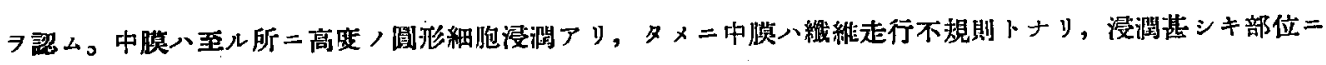

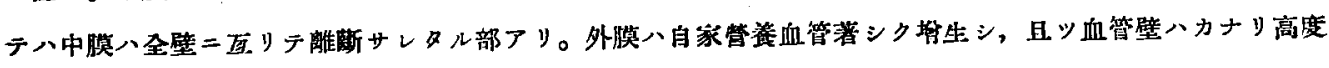

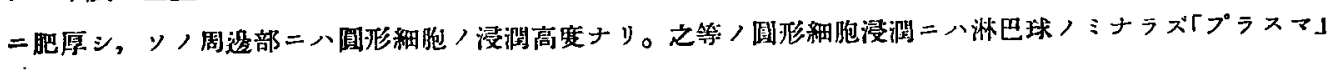
解胞多数二存在スルラミル。

\section{第 3 章 總 括}

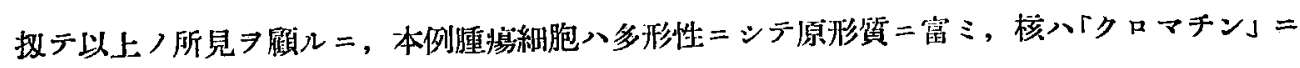
富ミテ竖染性ナルモノ存スルモ，多クハ「クロマチン」少クシテ泡狀ヨ呈スルモノョリナル。而

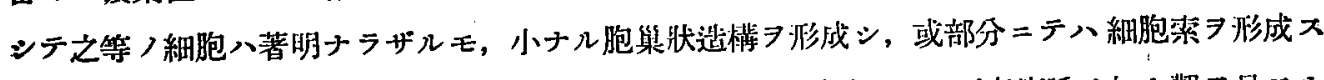

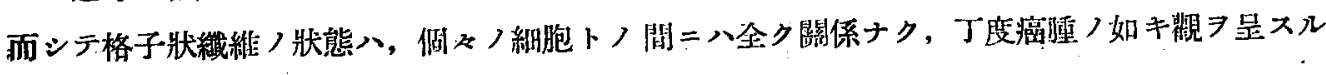
モノナリ。

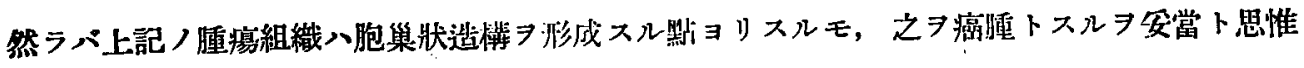


サレルモノナリ。又本例ハー見甚シク內被細胞腫=類似スル點ヨ有セリ。件シ闲臟二於ケル惡

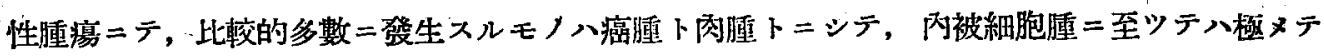

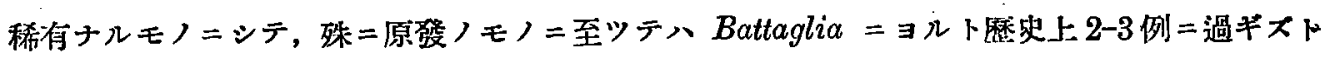

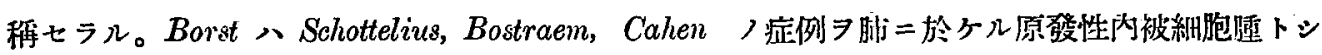

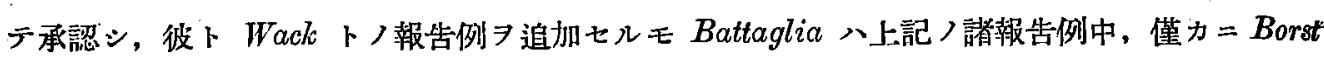

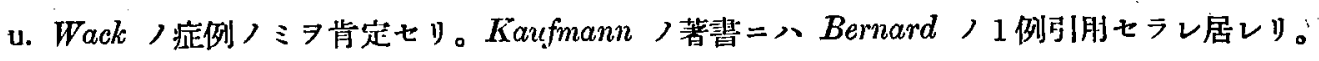

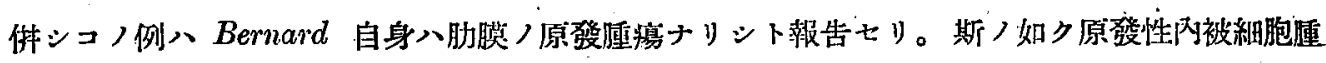
八稀有ナルモノナルモ, 續發性ノモノ八此较的屡々見ラルルモノノ如シ。藤原, 堀不, Schöppler

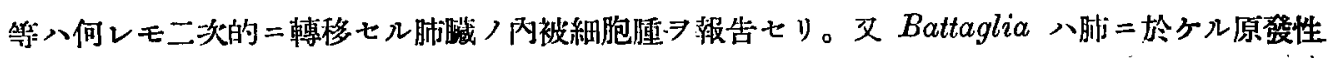

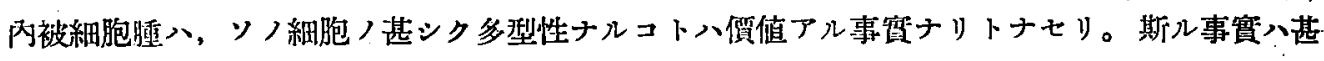
シク本例 內被細胞癌腫トシテ肯定セシムルモノナルモ, 內被細胞腫トシテハ肋膜其他何處二

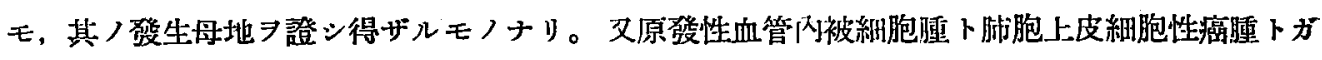
非常二類似スルコトメWeissmann，發表スルトコロナルガ, 本例 =於テモ次二述べルガ如キ

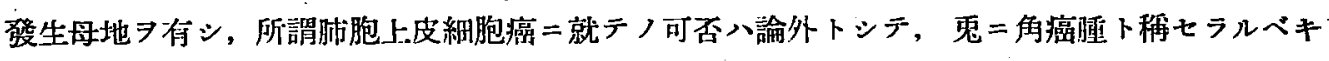
モノニハアラズヤ。

1）發生母地。原發性湖臟癌腈ノ發生母地トシテハ, 要スル＝1）氣管枝粘膜，圓杜上皮紐 胞，2）氣管枝粘膜粘液腺上皮細胞，3）所謂肺胞上皮細胞ノ三ヶ所ガ擧ゲラル。而シテ第三ノ 肺胞上皮細胞ヨリ發生スルトナスハ，異論アリテ其ノ報告例モ極メテ少ク稀推二屬ストナスへ シ。所謂肺胞上皮細胞下稱七ラルルモノ二就テ形態學上ヨリ上皮細胞說ヨナスモノニKöliker 始メトシテ Eberth, Hertz, Arnold, Meyer, Weber 等アリ。其ノ後其ノ細胞機能上ヨリ中还葉 性細胞, 即千組織球性細胞トナス者，Lang, Policard, Fried, Chiodi, Loreti-Zaietta, 植木等 ノ說有カトナリ。次イデス Hochheim, Briscae, Westhues, Lange, Guieysse-Pellissier, Seemañ,

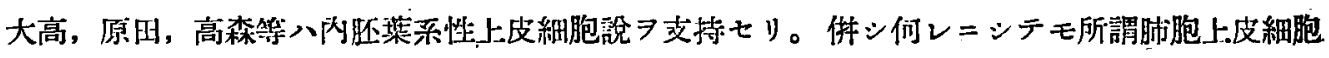
ヨリ癌發生ヨミルコトハ, 形態學的二八瑟メラレテ居ル狀態ニシテ, コノ報告例ヨナセルモノ = 1894 年, Siegert /例, 1902 年ノDömeny /報告习始メトシテ, Breckwoldt, Schmorl,

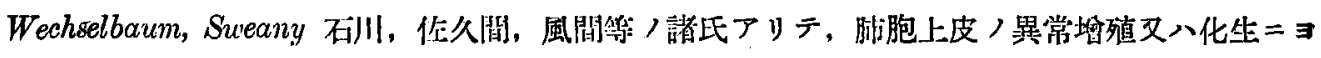

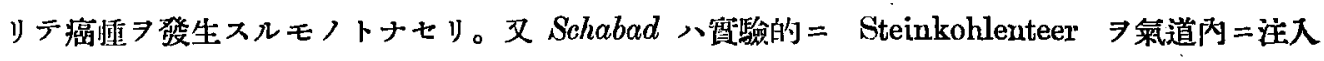

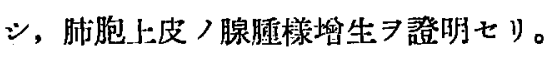

翻ツテ本例

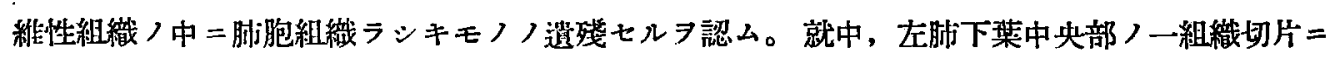

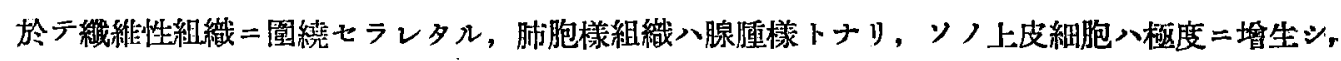
既二惡性化シ腫瘍細胞トナルヨ認ムルモノナリ。是本腫源/發生母地トシテ思肯セシムルモノ ナリ。郎チ本腫煬八先賢諸家ノ云フ所謂肺胞上皮細胞ヨ゙ 潑生母地トナスモノト肯定シ得にキモ 
ノテランカ。件シ所謂肺胞上皮細胞ノ本態二就テ異論アルガ如ク，コノ發生母地二關シテモ, 詳細二觀察スルトキ肺胞上皮細胞トナス，疑問ノ餘地ナキニ非ズ。郎チ所謂肺胞上皮つ腺腫

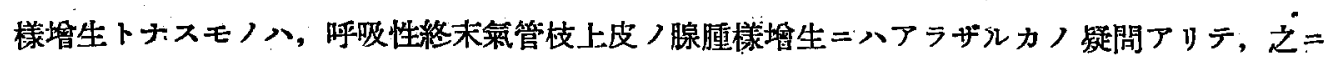
關シテハ今日解決スル材料ナキモ, 本例二於テハ腺腫樣增生ヨナスモノノ極ク小部分八肺胞上 皮ヨ思ハジムルモアルモ, 大部分八圓柱上皮細胞ニシテ, ヨノモノョリ多角骰子型ノ腫瘍細 胞二移行スルラ認ム。叉腺腫樣增生入大血管ナドノ附近二多手様ナルハ, 毛紬氣管枝〉變化ナ ランカラ思ハシムル點ナリ。要スルニソノ制斷二苦ンムト踓モ, 少クトモ本例入呼吸性終末氣 管枝つ圆柱上皮細胞引發生母地卜思考スルラ安當トスルモノナランカ。

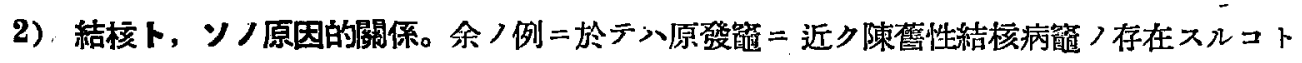
八前述ノ通リナルガ, 從來肺倵癌腫卜結核トノ原因閵係＝就テハ多數ノ記載二接スルコトヨ得

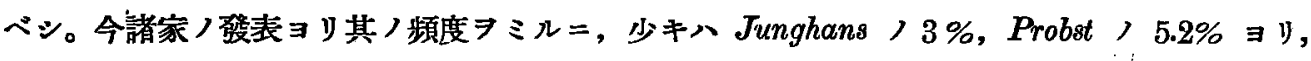
多キNDömeny 異ヨ有スルモノナルモ，多クハ10-20\% ヨ示セリ。而シテッノ因果關係二就キテハ, 古クョリ Rokitansky 一派, 或八今尚鈴汇, 杉山, 中村, Nowicki, Witold, Reinardt, Moize 等〉如ク 癌腫卜結核卜ノ拮抗性

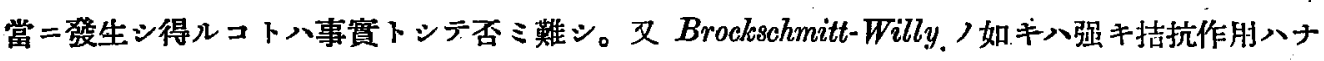
ク,而シテ文結核ノ存在八癌二對シテ,何等幸七スルコトナシト稱七リ。Nowicki-Witold八肺癌 䁌加ニツキテ論ジタル中二, 肺結核ハ一般二癌發生二對シ何等ノ關係ナシト, 而シテソノ原因

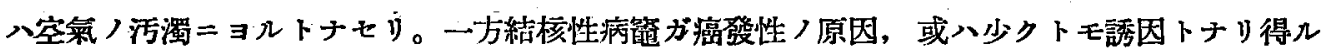
トナス者 $=$ Ribbert, Tucker, Vasic, Wolf, Basch, Schwalbe, Friedländer, Derischanoff, Ssipowsky, Hildbrand, Perrone, Beureuther, Fleckseder, Syrek, Adam, Peters, Wilhelm, Renner, Carl, 村山, 植村, 田口, 茂木, 角田, 原时, 鈴木(暂), 和辻, 青水, 長澤, 久保田, 奥原,

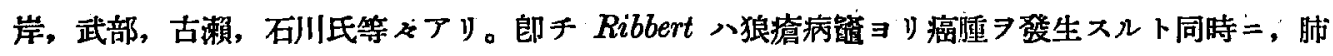
結核二於テ八氣管枝ノ上皮肧牙ガ離散シ，其ノ上皮組織ヨリ癌腫が發生スルコトヨ證明シ， Wolf-Richard 八周結核卜胃癌トノ合做例习報告シＳSäfwegberg 八同樣二胃二結核卜癌腫ノ合 件例 報告シタリ。Hampel 八消化管系統ニ 於ヶル6 侧ノ結核症卜癌腫卜ノ共存例

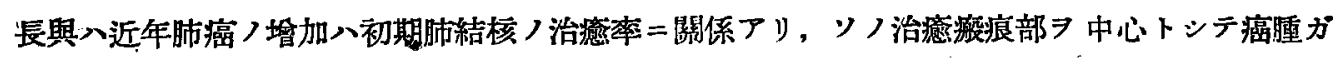
矮生スト言七, 武部, 田口, 堀池, 青水, 植村, 村山, 中村一野村, Renner-Carl, Junghans, Peterg, Gliegler, Derischanoff, Schwalbe 等八結核性空洞 $\exists$ リ肺渻ノ發生セル

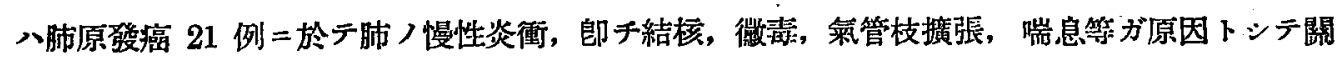
係スト發表シ, 岸八治虑的傾向强キ絬核症

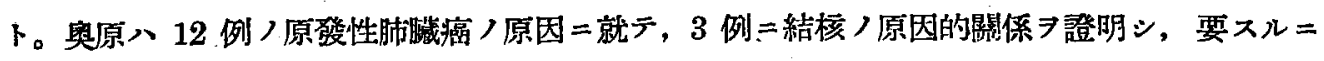
氣道ヨり來几刺载つ外三結核其他慢性つ間質炎 


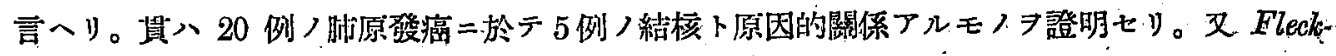

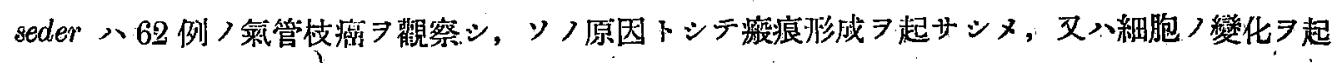

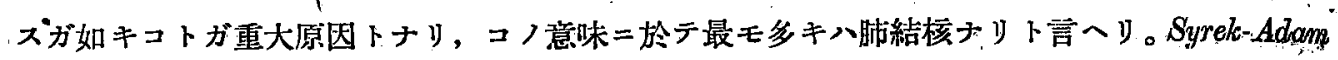

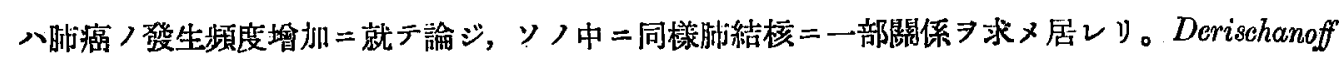

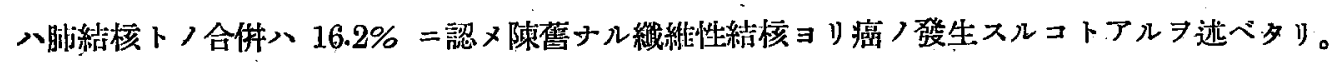

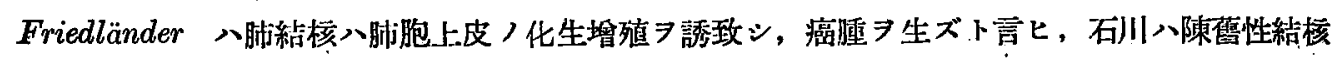

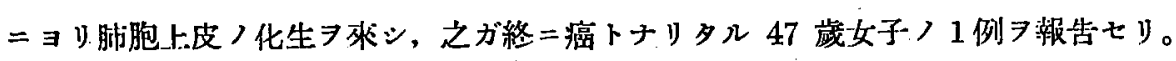

以上〉諸說 $゙$ 綜合スル 閶係アリトナス。

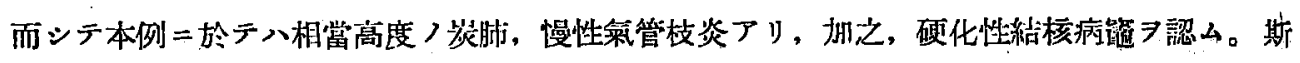

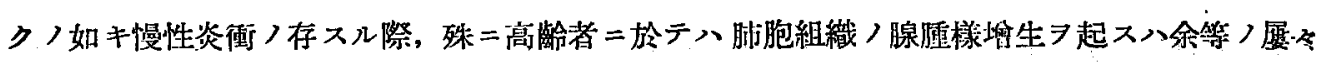

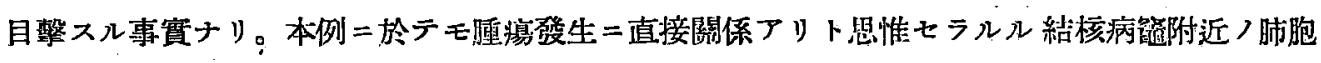

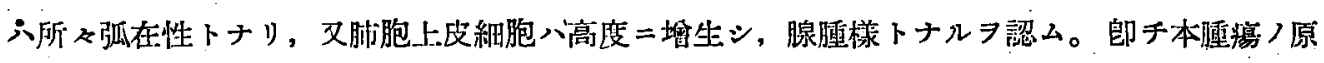

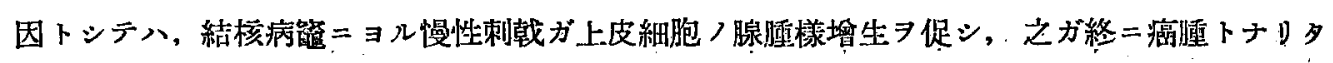
ルモノト思溚スれモノナリ。

3）其/他/原因的關保。上述絬核以外／原因或八誘因トシテ，一般二慥侮，素因，迷芽，

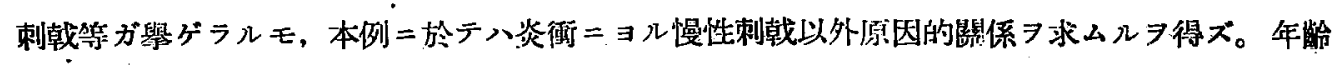

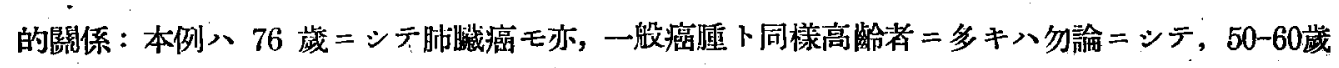

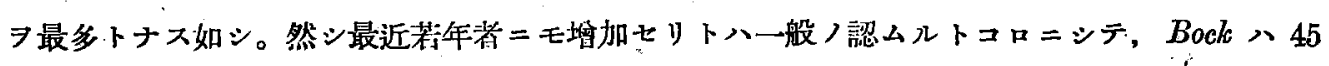

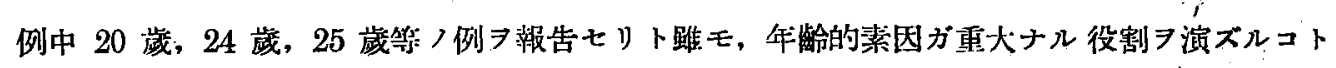

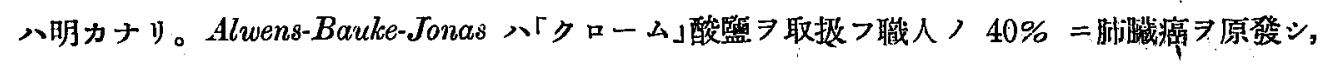

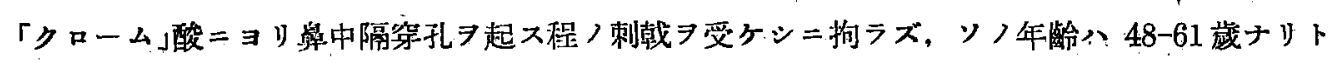

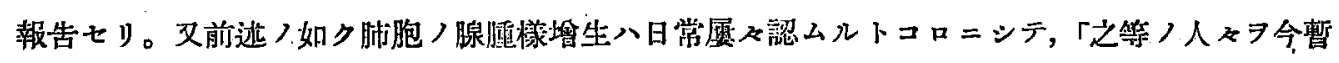
ク長生センメナバ」トハ恩们長澤㸚授〉度々言ハルルトコロナリ。

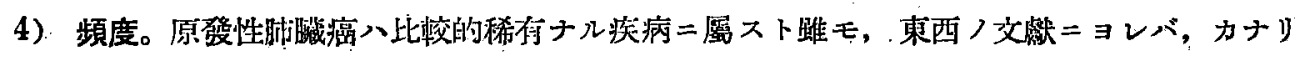
フ報告例二接スルモノナリ。ソノ一般頻度习觀ル二低率八Syrek-Adam，3.18\%，山極ノ 3.4 $\%$ シシテ, 高率八Dissmann-Erwin，10.8\%等テり。全解剖數二對シテハ低率ハSyrek-Adam

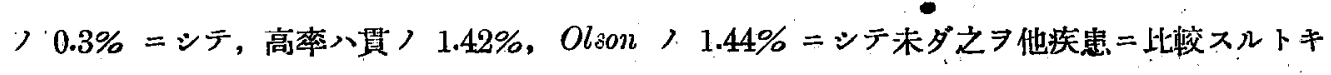

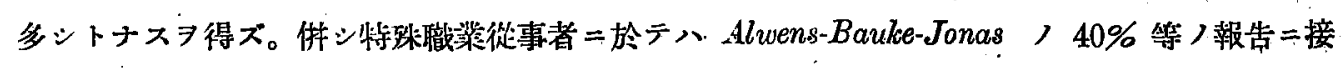
スルハ注目二價スベシ。而シテ近年增加ノ傾向アルハ一般ノ認ムルトンロニシテ鈴本, 稻田, 長與, Berblinger, Biberfeld, Olson, Syrek-Adam 等ノ記載スルトコロナリ。而シデ我ガ敉室二

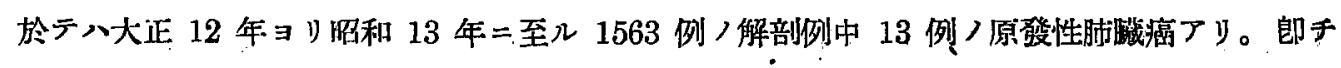
$0.86 \%=$ 當リ，又之 7 年度別二觀ル二大體平均七ル分布狀態 
憔トス。

5）性別關係。一般二男性二多シトナス毛ノニシテ，都ハ然性 2.7 倍, 買、男性 4 倍, 占瀨 八2.1 倍, 奥原入 2 倍, 篗州六女性二多クシテ男: 女 $=3: 4$ トナレリ。又外國三テ八Arkïn:

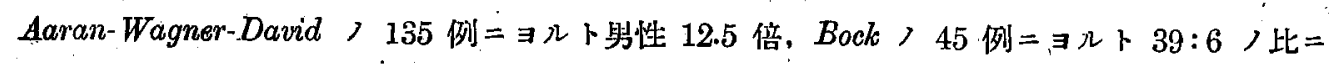

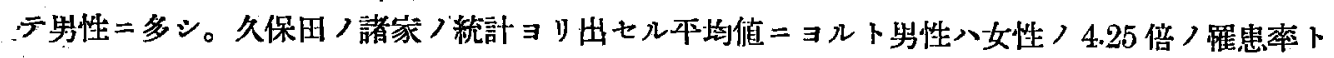
ナリ居レリ。我ガ郄室ニテハ 13 例中男性 10 例二對シテ呚 3 例ナリ。

\section{第 4 章 結 論}

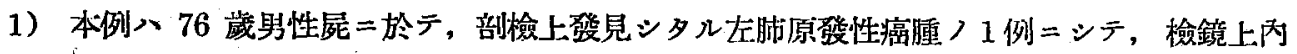
被細胞腫二甚シク類似セル所見习有スルモノナリ。

ミ）本例ノ弡生母地八, 所諸脯胞上皮細胞ノ本態=關シテハ, 今日之ヨ論外トナシ，少クト

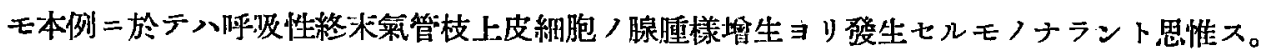

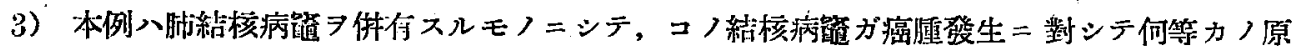
因的關係习演ジタルモノニ非ズヤト思考スルモノナリ。

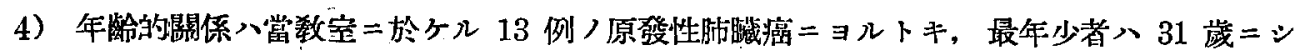
テ,'最高ハ本例ノ 76 歳ナリ。而シテッノ年階的分行ハ大體平均セり。

5）頻度八當教室 1563 例ノ總解剖數中, 原發性肺膆癌 13 例ニシテ, $0.86 \%$ 二相當ス。

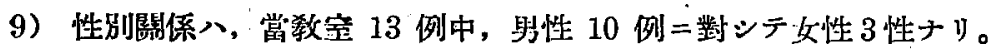

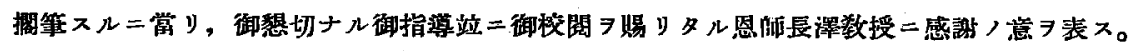

\section{文獻 (五十音覑)}

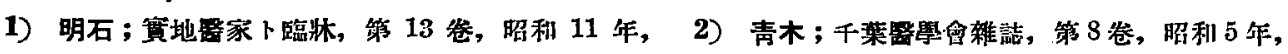
3) Alwens-Jonas; Arch. Gewerbepath. 7, H. 4. 1936 年, 4) Alwens-Bauke-Jonas; Münch, med. woch. Nr. 12, 1936 年, 5) Arkin-Aaran-Wagner-David; J. aner. med, Assoc. Nr. 8. 19

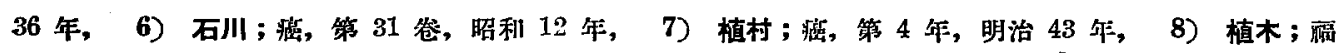

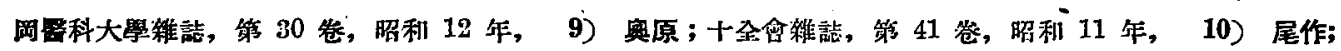

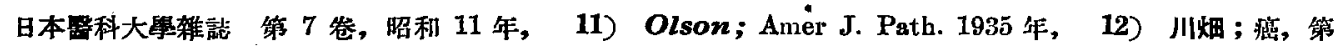

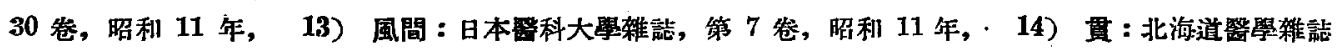

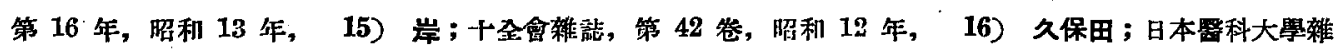
誌、第 7 卷; 昭利 11 年, 17) Kuroda-Kawahata; Z. Krebsforschung 45̃. H. 1. 1936 年, 18) Krumbein; Virch, arch. f. path Anat, u. Physiol, Bd. 249.

19) Koelsch; Arch gewerbepath.

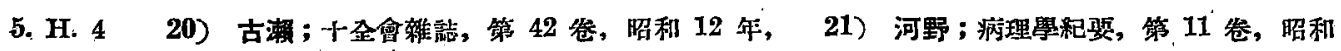
11 年, 22) 琣井; 猃歁卜治療, 第 24 卷, 昭和 12 年, 23) 佐久間; 日本器科大學雜誌, 第 7 卷, 昭和 11 年, 24) Schabad; Z. Krebsforschung 1932 年, 25) Syrek-Adam; Z. Krebsforschung 1932 年, 26) Schwalbe; Virch. archiv. Bd. 149. 1897 年, 27) Siegert; Virch. Areh. Bd. 134 1894 年；28）Sweany; Arch. of path 1935 年，29）鈴木; 癌, 第 27 替, 昭和 8 年, 30) Ssipowsky; Z. f. Krebsforschung Bd 36. 1932 年, 31) 田口; 熊本學會雜誌, 第 5 替, 昭和 4 年,

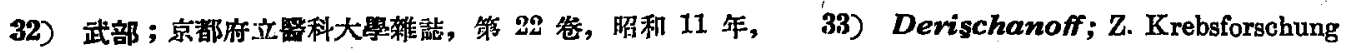


H. 1. 1932 年, 34) Dibble; Lancet, 1934, II. No. 18. 35) Dissmann-Erwin; Z. Krebsforschung H 5, 6. 1932 年, 36) Dömeny；Zeitseh. f. Heilk. Bd. 23, 1902 年 37) 最澤; 病理卜治境,

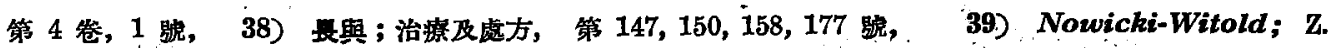
Krebsforsch. H. 1. 1932.年 40) Battaglia; Virchow arch. Bd. 261, 41) Bcck: H. E.; Münch. med Wochschr. 1935, Nr. 52: 42) Brockschmidt-Willy; Beitr. Kliṇ. Tbc, 1935 年, 43)

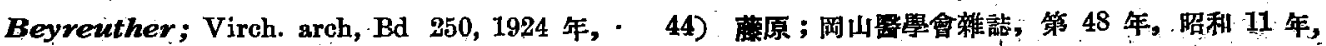
45) Fleckseder. R; Münch. med. Wochschr. 1936, Nr. 39. : 46) Friedländer; Fortschr. d. Med 1885 年, 47) Fischer-Wasels; Frankf. z. Path. H. 2. 1936年, 48) FinedJames-J.Ján-

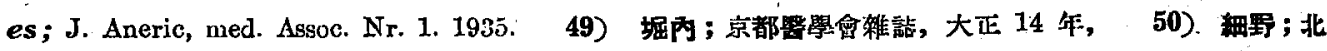
越學學會雜誌，第 31 年，大正 5 年，51) Henke-Silberberg; Zentbr. f. allg. Path u Path. Anat,

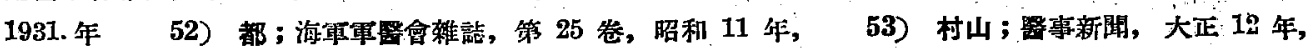
54) Junghans H.; Z. f. Krebsforsch. Bd. 29. 1929. 年 55) Loreti-Zaietta; Zentbl. f. allg Path u. Path. Anat Bd. 67. 56) Reuner-Carl; Beitr. klein. Tbc. 1934. 年 57) Ribbert; Dentsch med. Wochsch 1924.年 58) Weissmann; Erankf. z. Path. H. 4 1935.年

附 圖 說 明

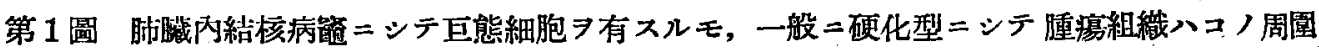
二隼生ス。

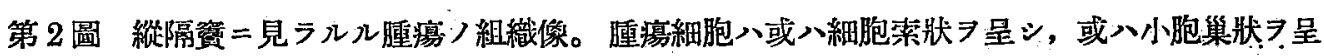

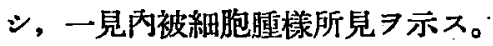

第3國同上ビルショウスキー氏染色棌本。

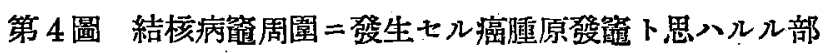

第 5 圆 -同上强撗大。

第 6 圖肺䐟內腫瘍轉移筑。

守 川秀 論 文 正 誤 表

日本罢科大學雅誌第 10 卷第 8 路(昭和 14 年 8 月 15 日發行)

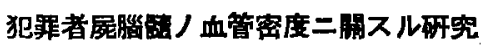

\begin{tabular}{|c|c|c|c|}
\hline 頁 & 行 & 瀷 & 正 \\
\hline \multicolumn{2}{|c|}{$\begin{array}{l}1034 \text { 頁最下行 } \\
1035 \text { 貝下 } \equiv \text { y } 5 \text { 行目 }\end{array}$} & 吾数室二於ヶル〜 & 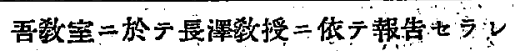 \\
\hline \multicolumn{2}{|c|}{ 2050貝1 105 行日 } & 1412. 35 gr デアル。 & 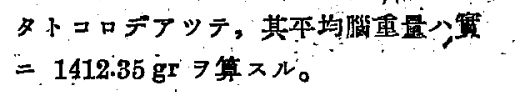 \\
\hline 1048 & 下ヨy 4 行目 & 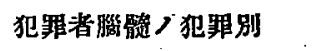 & 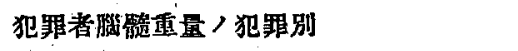 \\
\hline 1049 & 下ョリ7行目 & 非犯罪者例トシテ對照例 & 非犯罪者トシテノ辐照例 \\
\hline 1058 & 上 $\equiv y \cdot 5$ 行目 & 犯罪例 & 犯罪著例 \\
\hline
\end{tabular}


森户諭文附圖

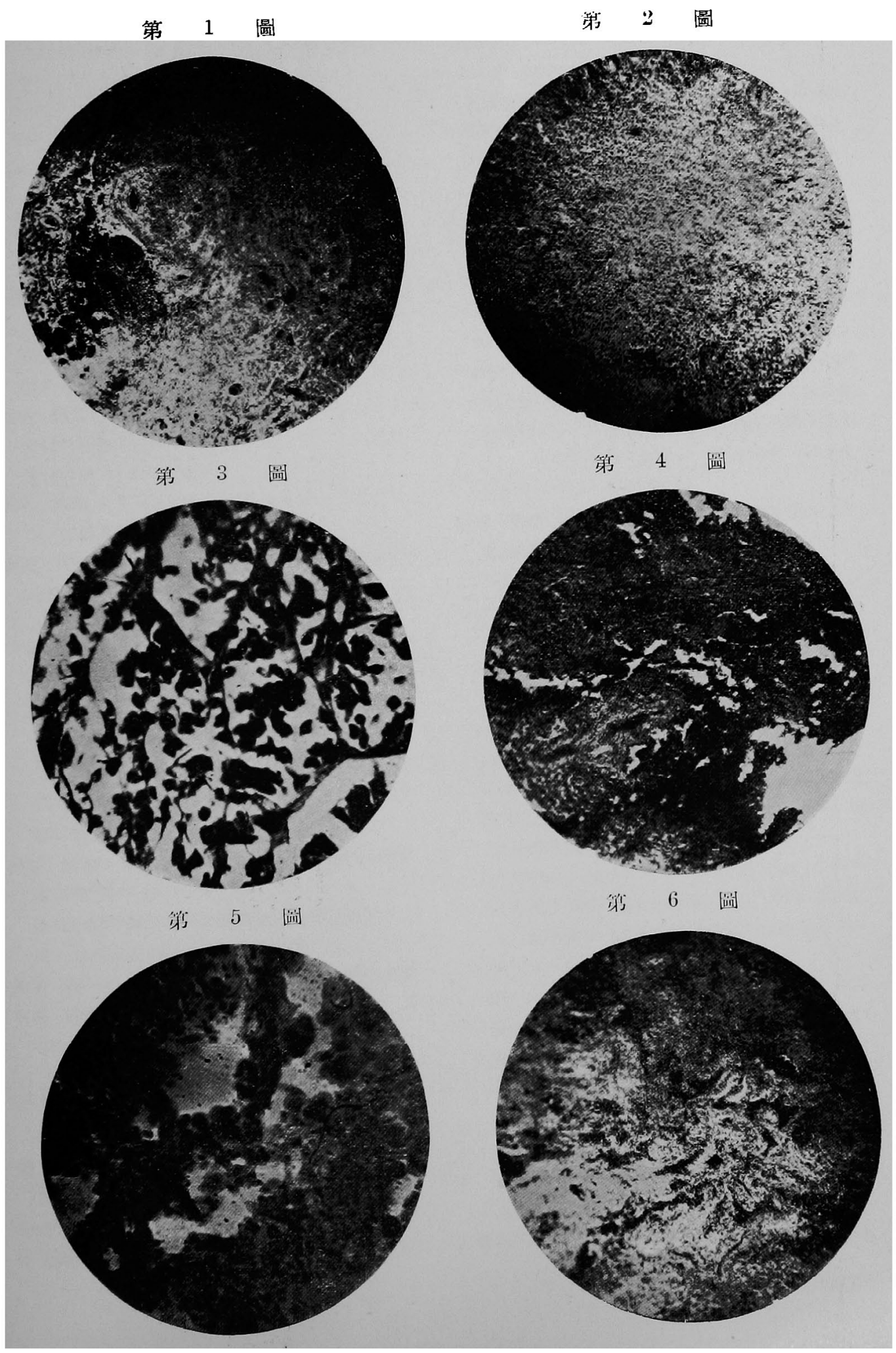

